\title{
THE IMPLICATIONS OF SAVING AND INVESTMENT BALANCE ON ECONOMIC GROWTH OF THE REPUBLIC OF MOLDOVA
}

\author{
Rodica PERCIUN \\ Associate Professor, National Institute for Economic Research of ASM, Republic of Moldova \\ Tatiana PETROVA \\ Scientific Researcher, National Institute for Economic Research of ASM, Republic of Moldova \\ Corina GRIBINCEA \\ Scientific Researcher, National Institute for Economic Research of ASM, Republic of Moldova \\ date of paper receipt: \\ 14.11.2017. \\ date of sending to review: \\ 16.11.2017. \\ date of review receipt: \\ 21.11.2017.
}

Orginal article

\section{SUMMARY}

The saving and investment balance can ensure the stability of the financial market. The aim of the study is to analyse the dynamics of the saving-investment balance in the Republic of Moldova and its impact on economic growth. The role and possibilities of attracting foreign investments into fixed assets are presented. The indicator of investment growth with a low level of gross savings is a signal or a harbinger of a decline in economic growth. According to the National Bank of Moldova, legal export of capital from the Republic of Moldova takes only a small part in the process of export of capital. The leading role in the mechanism of transformation of savings into investment should belong to BNM.

Keywords: savings, investments, economic growth, financial stability, capital outflow.

\section{INTRODUCTION}

The saving-investment balance is not only an important indicator of monitoring financial stability in the Republic of Moldova but also a condition for the economic growth. In the neoclassical model, the equilibrium of saving and investment is the main condition of a self-regulating economy. The rate of GDP growth has a positive correlation to the average propensity to save. Through the mechanisms of transformation of savings into investment, the influence of financial factors on economic development is manifested. The greater the level of savings and investment in the economy, the greater is the rate of national income.

\section{METHODOLOGY}

The system of national accounts is based on the balance method of interrelated complex study of economic processes and the results of their activities. With the help of the national accounts system, the interrelations between economic processes and phenomena are revealed.

In a state of economic equilibrium I is equal to $S$, but in the active phase of economic development, as a rule $\mathrm{I}>\mathrm{S}$, as investments exceed savings. If investments lag behind savings, then growth in GDP is slowed. 
The current account balance reflects the movement of savings and investments of the domestic economy:

$\mathrm{CAB}=\mathrm{X}-\mathrm{M}+\mathrm{NY}+\mathrm{NCT}=\mathrm{S}-\mathrm{I}$,

where X - export of goods and services; $\mathrm{M}$ - import of goods and services; NY - net income from abroad; NCT - net current transfers; S - I (capital account) - is the internal balance of the economy, and $\mathrm{CAB}$ (Current account) external balance.

If the value of domestic savings is insufficient to finance domestic investment in an open economy, additional financing is attracted through external debt (D) or equity participation of foreign investors (E):

$\mathrm{S}-\mathrm{I}=\mathrm{CAB}+\mathrm{D}+\mathrm{E}$

The current account of the balance of payments represents the gap between national savings and national investment. The deficit of balance of payments indicates that the amount of the current account and the capital account are not balanced.

In most developed countries the correlation between the S - I / S does not exceed the level of 10\%; in countries with economies in transition, the threshold value is defined as:

$\mathrm{S}-\mathrm{I} / \mathrm{S} \geq 30 \%$

The criterion shows what percentage of the gross savings in the economy does not translate into investment (Бланшар, 2010). 


\section{THE IMPACT OF NATIONAL SAVINGS AND FIXED CAPITAL ACCUMULATION ON THE ECONOMIC GROWTH OF THE REPUBLIC OF MOLDOVA}

Figure 1 shows the impact of the level of savings transformation in investments on the economic growth of the Republic of Moldova. The savings level is calculated by the formula: S - I / S and it shows that the growth rate of investment with a low level of gross savings can be a signal or a precursor of a decline in the economic growth.

Figure 1 Influence of the balance of "saving-investment" on economic growth in the Republic of Moldova

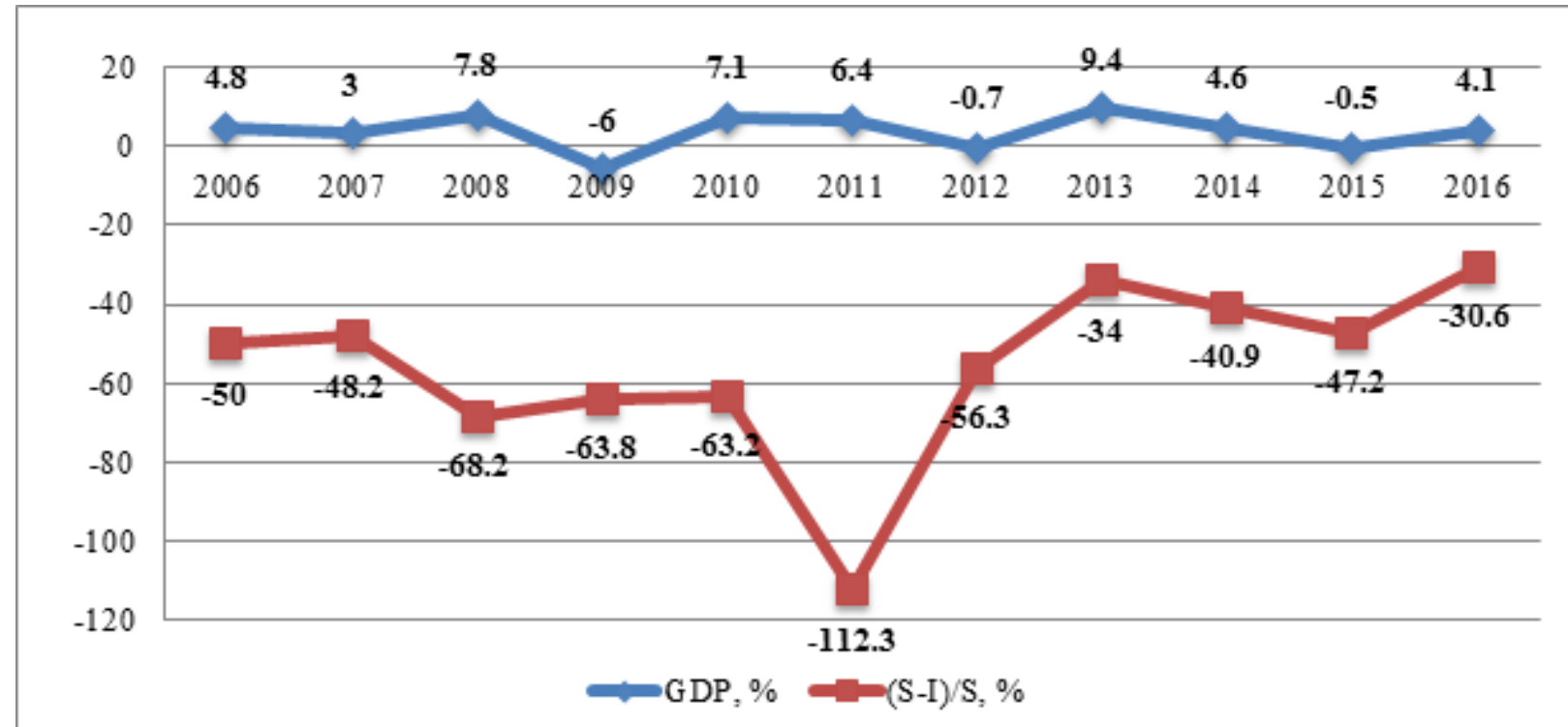

Source: calculated by the authors based in NBS data www.statistica.md

The decrease in the level of the savings-investment balance in the Republic of Moldova can be regarded as a lack of domestic funds for investment in 2008, 2011 and 2015. Along with other indicators of financial stability, this affected the decline in economic growth rates in 2009, 2012, and 2015, respectively. Table 1 shows the comparative data of national savings and fixed capital accumulations in relation to GDP in emerging economies, as well as the level of net capital inflows as the sum of net direct investment positions.

Table 1. Balance of payments for some countries for 2016, in \%

\begin{tabular}{|l|r|r|r|r|r|r|r|r|}
\hline & Bulgaria & Romania & $\begin{array}{l}\text { Azerbai- } \\
\text { jan }\end{array}$ & Belarus & Armenia & Georgia & Ukraine & Moldova \\
\hline $\begin{array}{l}\text { Gross } \\
\text { savings (\% } \\
\text { of GDP) }\end{array}$ & 23 & 24 & 29 & 26 & 18 & 21 & 15 & 17 \\
\hline $\begin{array}{l}\text { Gross cap- } \\
\text { ital forma- } \\
\text { tion (\% of } \\
\text { GDP) }\end{array}$ & 21 & 26 & 29 & 30 & 21 & 32 & 15 & 22,5 \\
\hline $\begin{array}{l}\text { FDI, net } \\
\text { inflows (\% } \\
\text { of GDP) }\end{array}$ & 2,4 & 2,9 & 11,9 & 2,6 & 3,2 & $2,26^{*}$ & $0,04^{*}$ & 1,8 \\
\hline
\end{tabular}

Note: ${ }^{\star}$ data for 2015

Source: IMF data www.data.imf.org 
From the point of view of the overall adequacy of investments, the ratio of the gross accumulation of fixed capital in GDP is most important. The rate of accumulation is a consolidated macroeconomic indicator reflecting the final balance of the actions of all economic, legal, institutional and other factors regulating the volume and structure of investment activity. By the level of formation of fixed capital, the Republic of Moldova lags behind countries actively developing their industrial potential, with the exception of Ukraine, while the savings rate in these countries provides a significant share of national investment. At the same time, developing countries are actively using foreign investments to modernize and develop the economy. In comparison with other countries with emerging economies in the Republic of Moldova their level is insignificant.

According to published estimates (Shneider, 2003) for countries with transitional economies, the minimum threshold value of gross fixed capital formation is estimated at 25\% of GDP. Otherwise, the normal process of reproduction of fixed capital is violated as the foundation for the constant modernization and competitiveness of the national economy. According to McKinsey experts (McKinsey \& Company), currently for each 1\% of the growth of the economy, it is necessary to increase the volume of investments to GDP by 2.5 p.p. (i.e. dynamically growing countries need more active investments).

Figure 2 The dynamics of the main indicators of investments

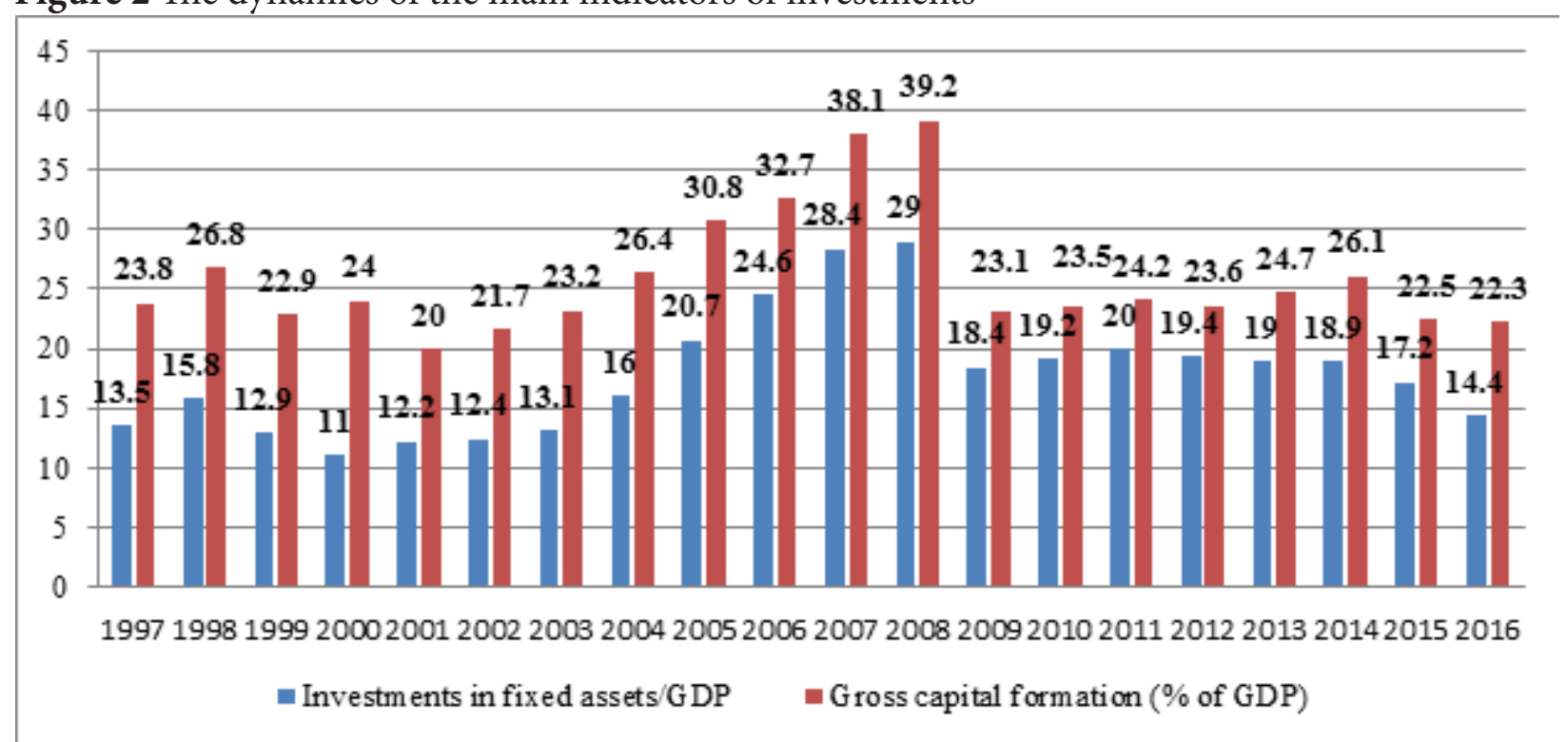

Source: elaborated by the authors based on NBS data www.statistica.md

The amount of investments in long-term tangible assets differs from gross capital formation primarily on the amount of capital repair costs and the cost of uninstalled equipment. The highest level of gross capital formation in Moldova was achieved before the crisis of 2009. The level of gross capital formation increased in 2008 to 39.2\% / GDP and 29\% of investments in fixed assets / GDP. The growth was also noted in 2014 to $26.1 \%$ / GDP and $18.9 \%$ of investments in fixed assets / GDP. In 2016, investments fell by 4.0 p.p. compared to 2009, and the accumulations - by only 0.8 p.p. Accumulation in 2016 compared to 2014 (when the highest level was recorded for this indicator) declined by 3.8 p.p. and respectively in 2016 investments fell by 5.6 p.p. compared to 2011 . 
Figure 3 Use of fixed capital formation and investments in long term tangible assets

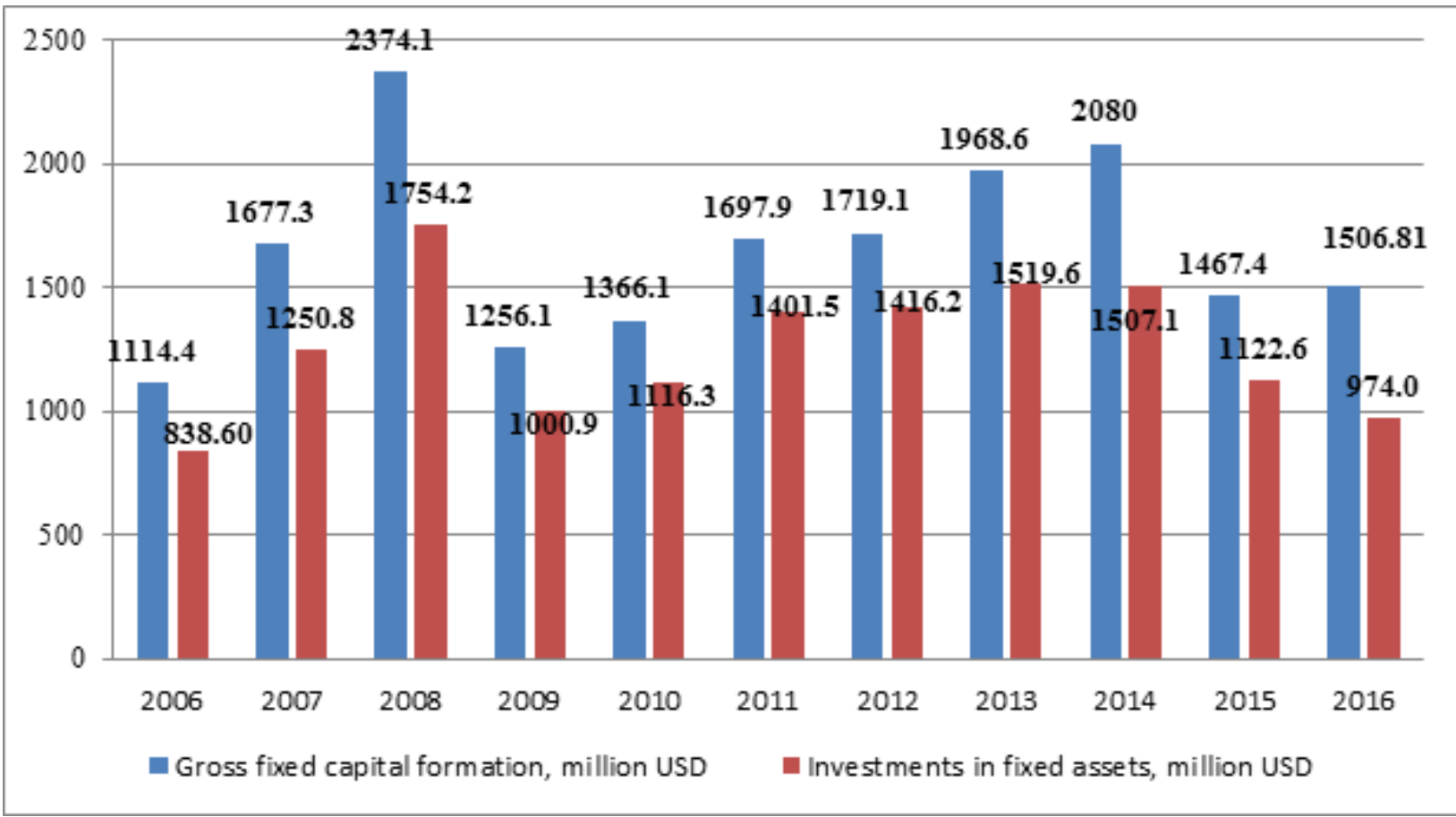

Source: elaborated by the authors based on NBM data www.bnm.md

In 2016 investments in long-term tangible assets amounted to $64.6 \%$ of gross fixed capital formation, which indicates a significant component of capital repair expenses in the Republic of Moldova. A serious problem is that in the post-crisis period, in order to restore growth, investments have not reached the values of pre-crisis years.

Against the background of general under-accumulation of capital in the economy, nevertheless, we can assume some "conditional overheating" of the economy in the pre-crisis period (2008 and 2014). This situation is due to the fact that in conditions of slow reforms when certain indicators go far ahead, it is necessary to establish the incentive correspondence of many components and overcoming imbalances, in the transformation of savings into investments. Expert Fedorov V. notes the danger of the situation, as economic growth has no reliable basis and unjustified distortions in the structure of the есоnomy (Федоров, 2006).

These data show the instability of investment opportunities within the limits of the changes in the investment climate, depending on economic, political and financial (internal and external) factors. Investment activity in Moldova can be characterized as a country with unstable and risky conditions, which has a negative impact on attracting investors.

Gross savings of the Republic of Moldova do not cover the investment needs of the economy, and the share of the formation of fixed capital in the last 2 years was on average less than $23 \%$ (Сенчагова, 2005) of GDP, which is not enough for effective development and modernization of the economy. 
Figure 4 Dynamics of the internal balance of "savings and investments" in the economy of the Republic of Moldova

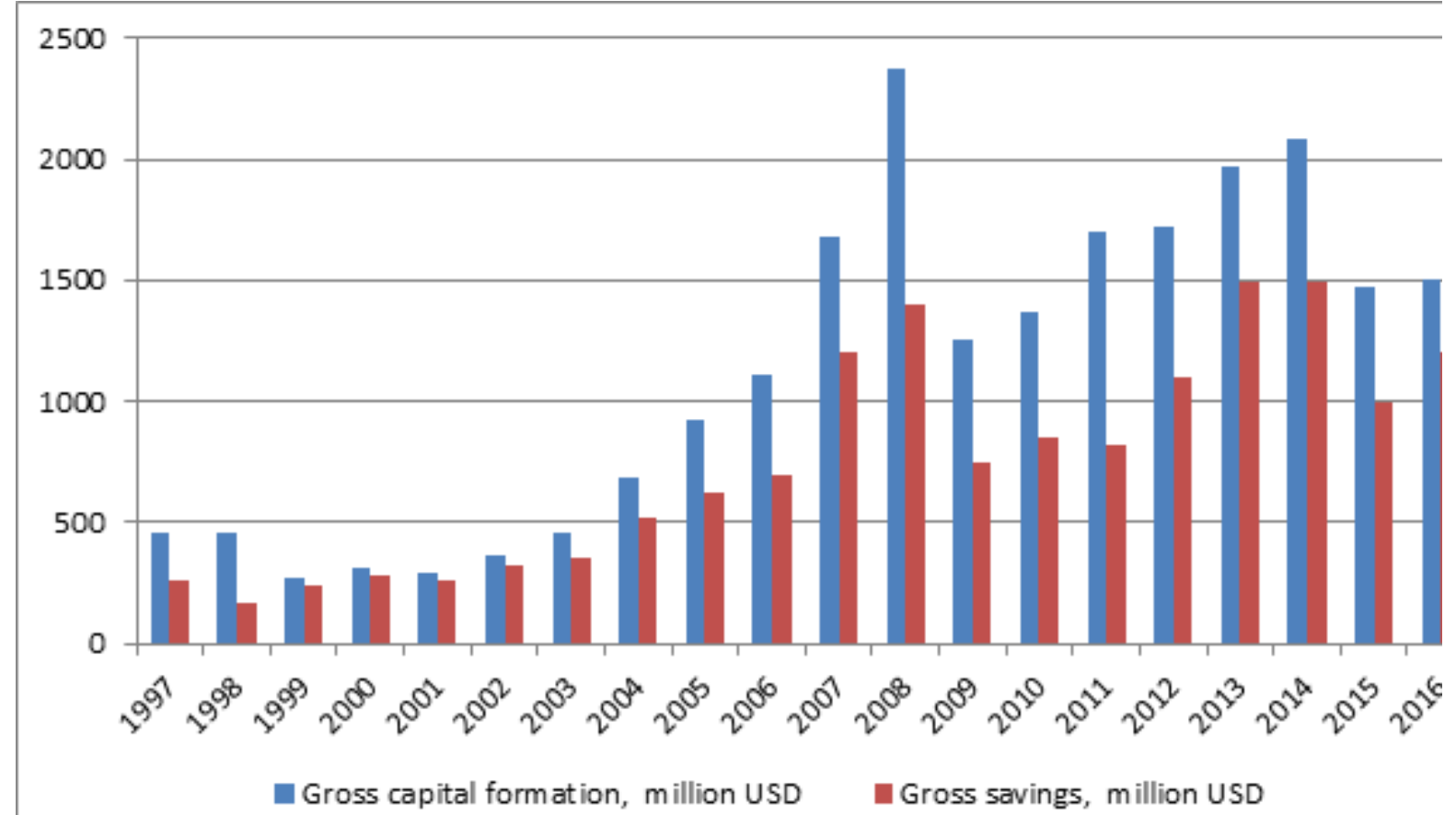

Source: calculated by the authors based on NBM data www.bnm.md

The concomitant decline in gross capital and gross savings is one of the most vulnerable trends in the national economy. During the crisis of 2009 and 2015 there is a sharp decline in savings and investments. Two years before the crisis, were registered some signs of economy overheating: an increase in investment and savings and an increase in domestic and external loans. The increase in gross savings led to a significant increase in investments in long-term tangible assets in 2008.

In the context of financial stability it is important to find the optimal balance between saving and investment, which would allow the country to have sustainable economic growth. Authors argue that during 1997-2016 investments in fixed assets are higher than gross savings. Theoretically, Moldova should be in an active phase of growth, but in reality, growth in investments by gross capital formation indicator is below the recommended threshold. During the period of economic transformation, especially after passing the crisis, this indicator should be higher, as a reduction in incomes leads to a drop in the level of savings, which ultimately leads to a reduction in investment and a slowdown in the development of the economy.

Figure 5 shows the correlation between the degree of transformation of savings into investment and the economic growth of the country. 
Figure 5 The degree of savings transformation into investment and the economic growth of the Republic of Moldova

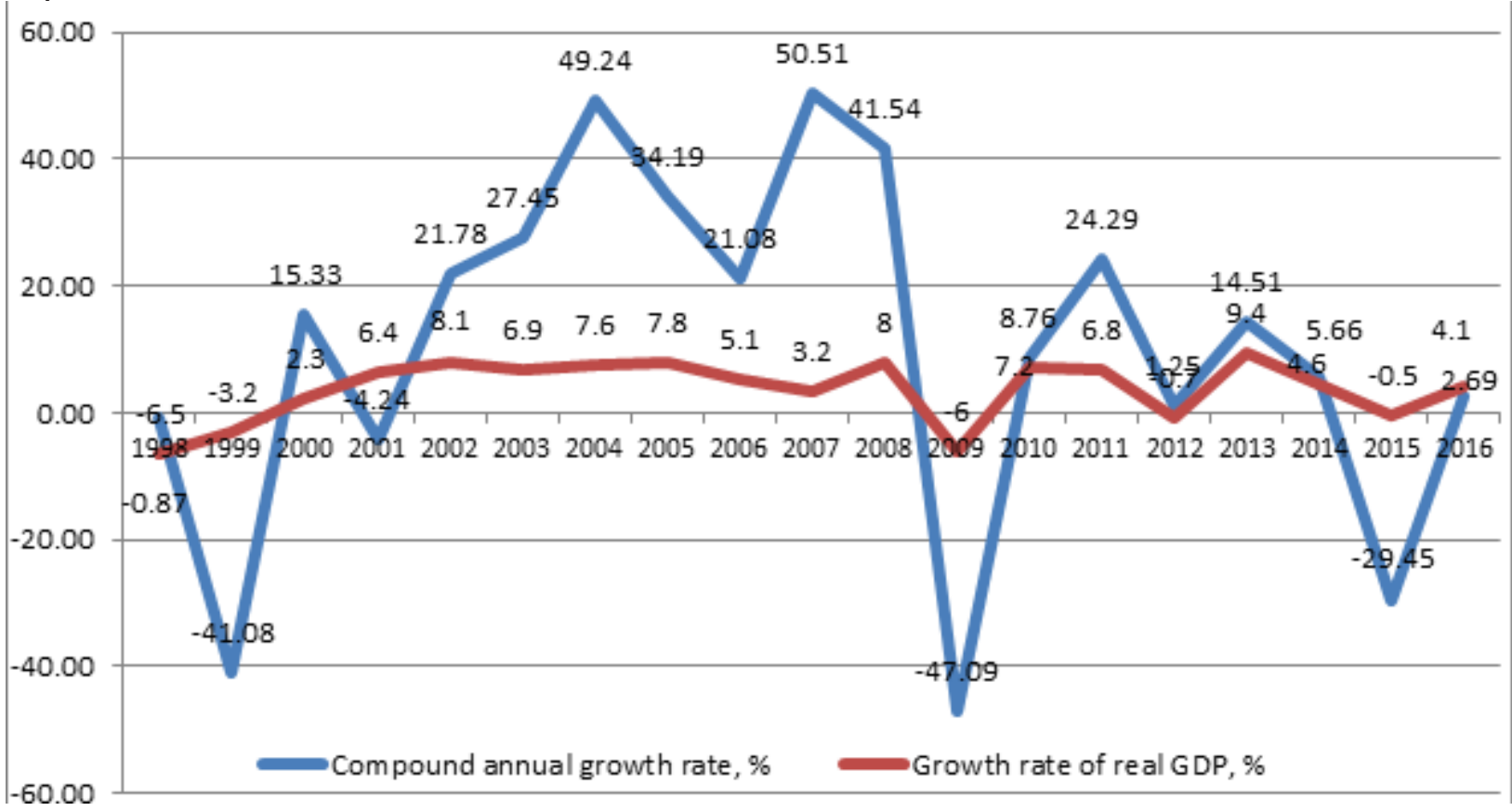

Source: calculated by the authors based on NBS data www.statistica.md

\section{EXTERNAL ECONOMIC FACTORS OF FINANCING WITHIN THE OPEN ECONOMY OF THE REPUBLIC OF MOLDOVA}

The Republic of Moldova imports more goods than exports. The most significant impact on crossborder capital flows is provided by current transfers, including personal remittances. Thus, the current costs of imports are covered in a significant proportion by remittances. It can be concluded that about $60 \%$ of current transfers are received personal remittances.

Figure 6 Comparison of the total trade flows and remittances to the Republic of Moldova (current USD).

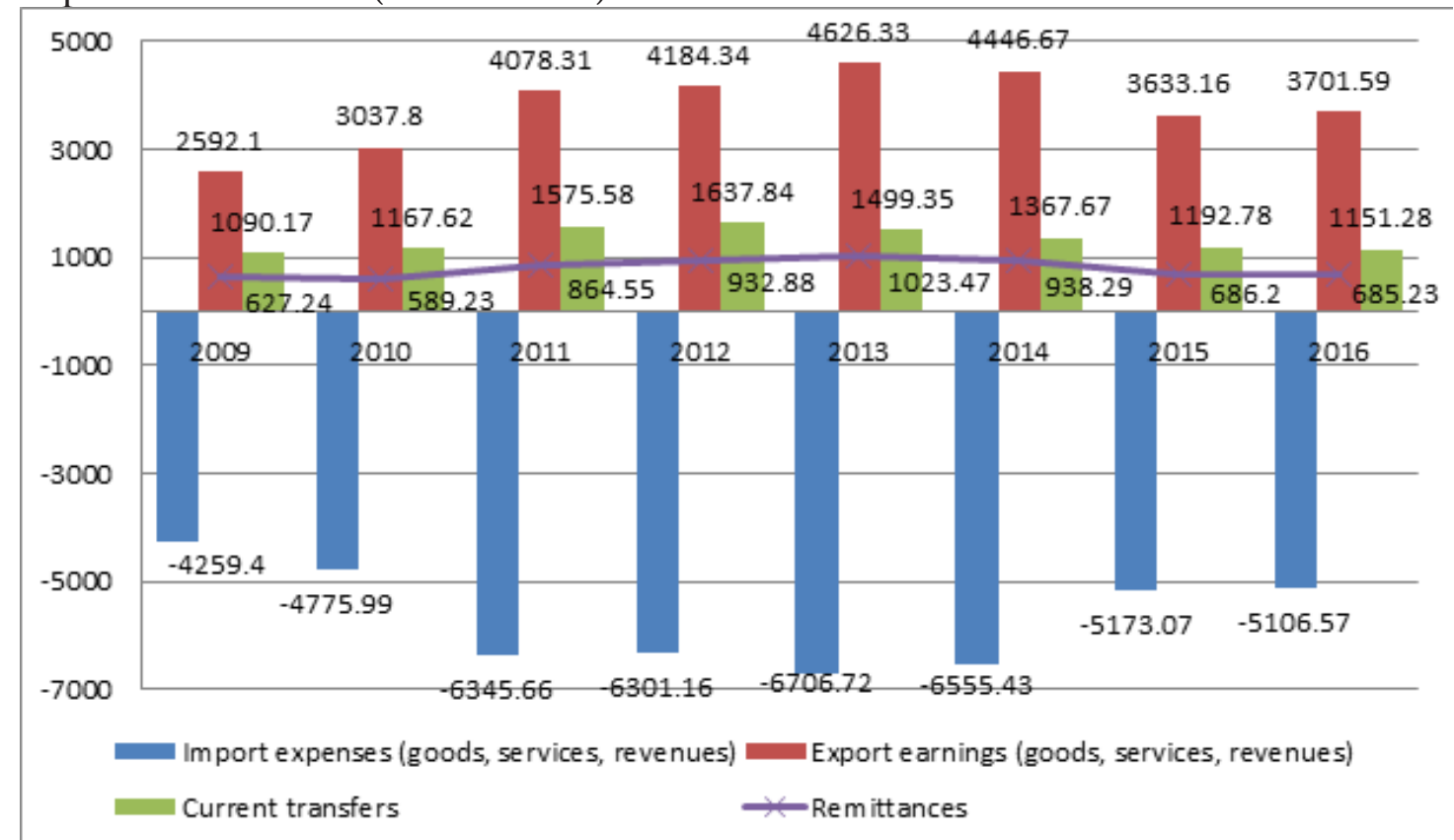

Source: calculated by the authors based on NBM data www.bnm.md 
Taking a look on imports increase compared with exports, we can affirm that Moldova has problems of competitiveness. The possibility of taking corrective measures to achieve a secure position in external payments (deficit of goods, services and incomes) is financed through private and formal transfers, financial flows and the use of reserve and other financial assets or through the import of foreign savings (borrowings).

On the account of capital transactions, a considerable amount of resources provides "rest of the world" to the Republic of Moldova. During the 2008 crisis, the amount of "borrowings" was 1002.59 million USD and 819.96 million USD in 2011 (more than 95\% of the savings level). Despite the fact that by 2015 net borrowing decreased to 390.8 million USD and amounted $39.2 \%$ to the level of savings or $6 \%$ to GDP, the dynamics of low investment level was reflected in the fall of Moldovan growth in 2015 (NBM, 2016).

Net capital inflows are analogous to the current account deficit and a sign that the economy works unstably. However, the share of foreign direct investment in total investments decreased up to $12.8 \%$ in 2016 (NBM, 2017).

Figure 7 Share of Foreign Direct Investment transformed in long-term tangible assets

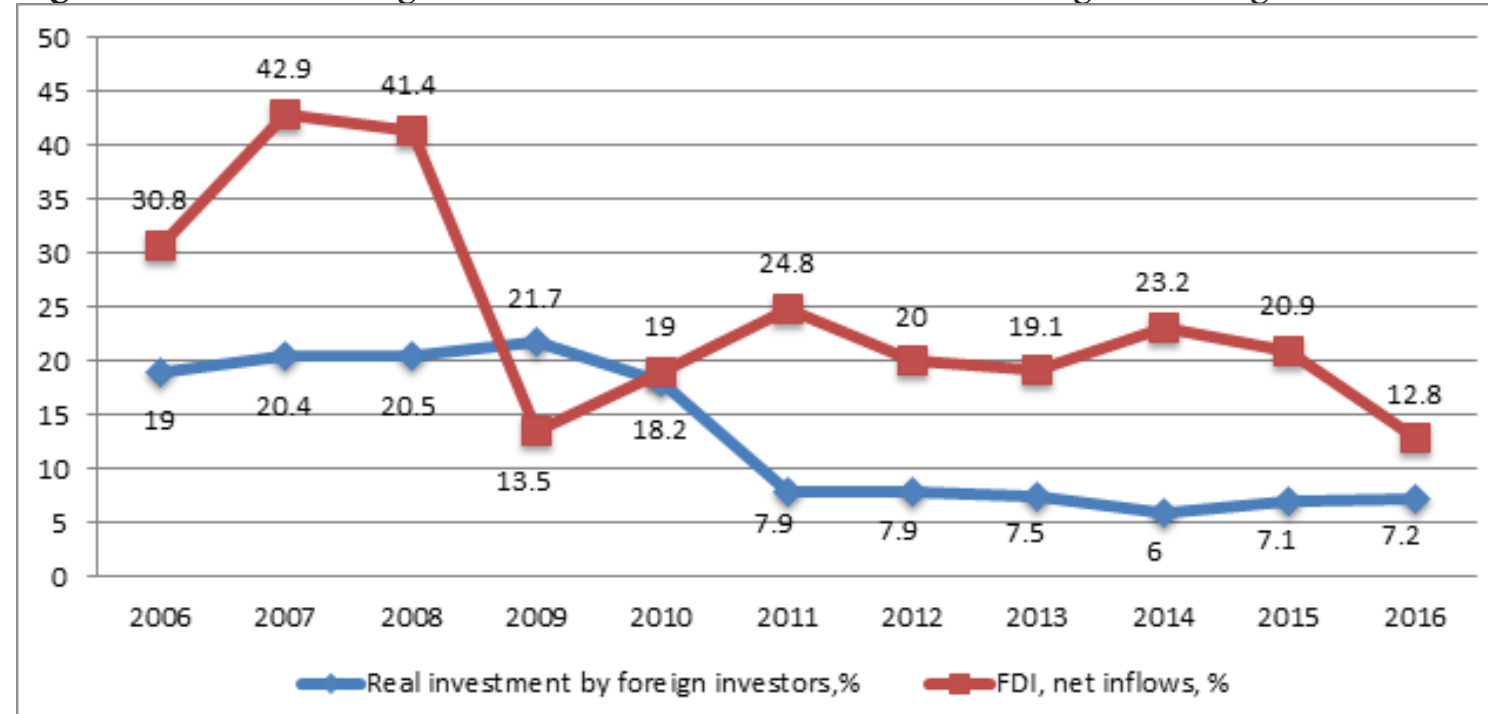

Source: elaborated by the authors based on NBS, NBM data www.statistica.md, www.bnm.md

A significant part of savings due to external sources of financing is not transformed into investments. On the one hand, foreign investments fill up the deficit of their own financial resources, create a basis for the development of production and, consequently, solve the problems of unemployment, and to overcome the structural crisis, etc. On the other hand, in the long term, an increase in paid foreign investment income could lead to a reduction in domestic savings and, as a result, a reduction in domestic investment and then in GDP. At the same time, only a small proportion of foreign capital is involved in the investment process.

Reduction of domestic investment creates a demand for cheaper international credit resources, which stimulates the growth of foreign debt. As a result of the growth of external borrowings, the financial account of the balance of payments is improving, but only in the short term. In the medium and long term the situation is reversed, as interest on debt and debt itself are paid. In the Republic of Moldova, the growth of the total external debt is much faster than the GDP growth.

$1 \quad$ Borrowing characterizes the excess or shortage of sources of investment financing in comparison with the expenses for the net acquisition of non-financial assets. At the level of the economy as a whole, net lending means acquiring financial assets from non-residents, and net borrowing means financial obligations to non-residents. 
Figure 8 The growth dynamics of gross external debt in relation to GDP growth and external economic balance of the Republic of Moldova

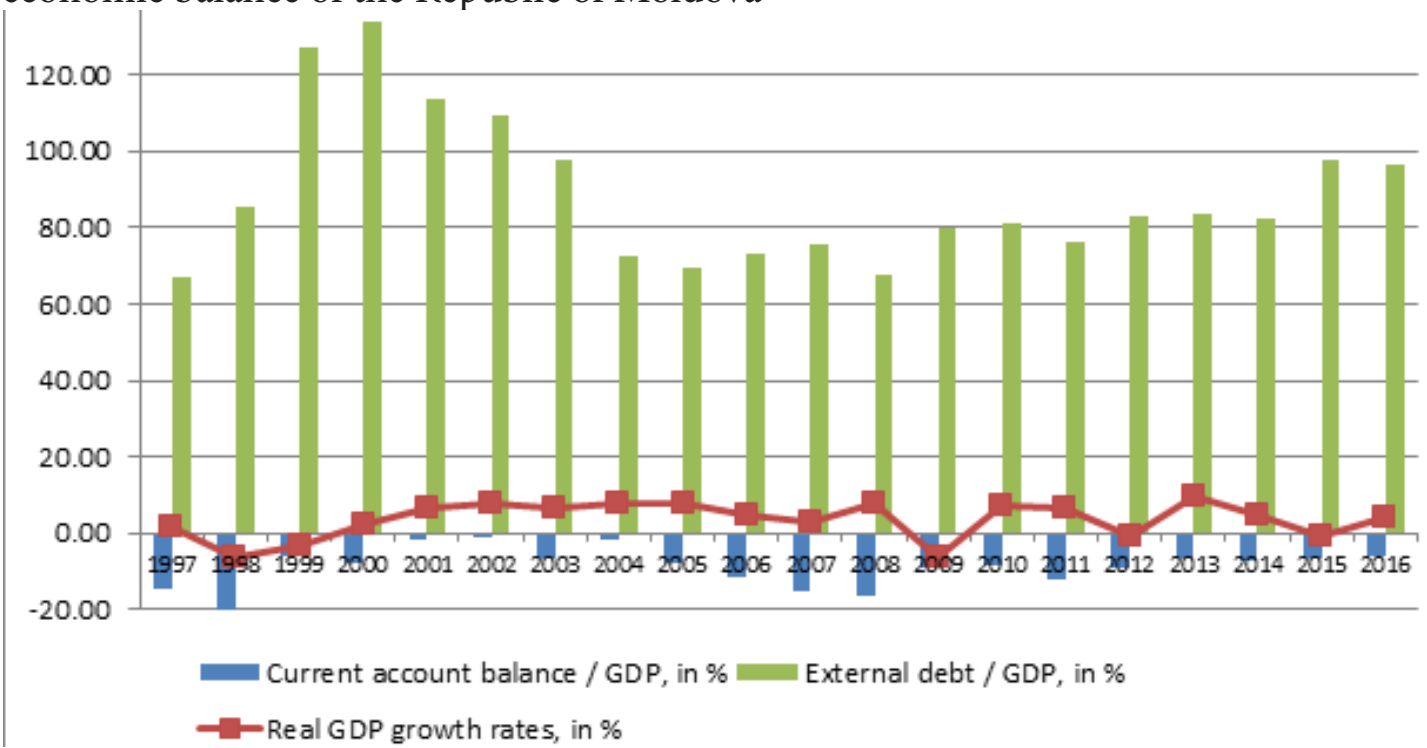

Source: elaborated by the authors based on NBS data www.statistica.md

A deficit of current account balance sheet reflects a structural imbalance between savings and investment. The increase of deficit of current account results in an increase of the budget deficit. In 2015 the budget deficit increased to 39\% compared to 2014. Despite the fact that in recent years the national budget deficit in Moldova is down by 1.9\% of GDP in 2016 and amounted 2487.1 million MDL, the state budget in 2017 consists of $1 / 3$ of external financial sources. The increase in the budget deficit leads to an increase in the current account deficit.

By international standards, the worst case of the current account in the Republic of Moldova is:

- The country has a budget deficit (expenses $>$ income);

- National savings are less than investments;

- Imports exceed exports.

The balance of savings and investments and their transformation increase are indispensable conditions for the effective functioning of the mechanism for ensuring financial stability. The reduction of national savings increases the investment deficit and, accordingly, causes a deficit in the current account, which can be financed by a net inflow of financial resources. The financial conditions for the activation of investment activity determine the financial stability of the Republic of Moldova. The approach of the financial crisis is signaled by the high level of current account deficit in relation to investments. 
Figure 9 Current account in relation to investments, \%.

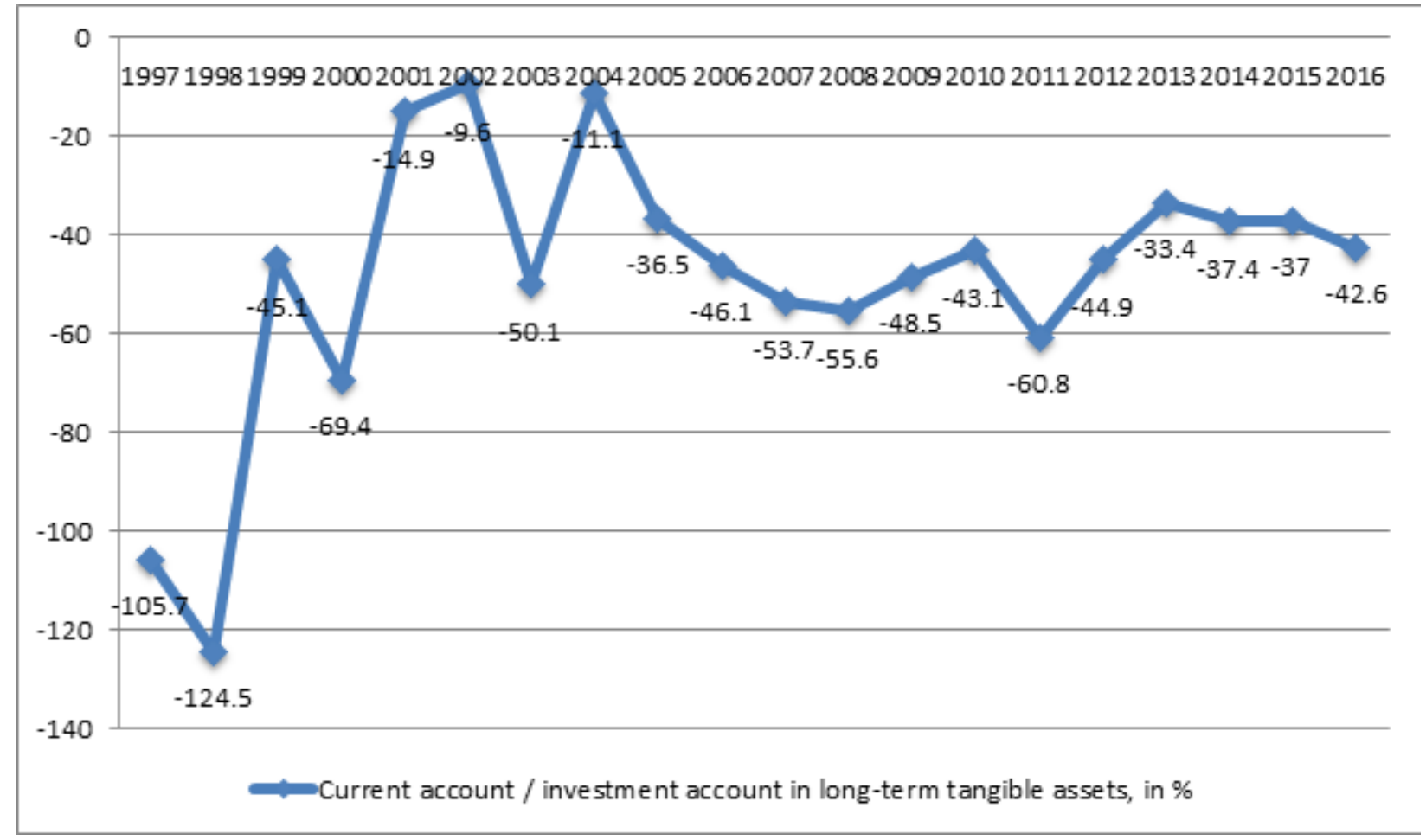

Source: elaborated by the authors based on NBM data www.bnm.md

If the deficit reflects a low level of savings and investment, it can be concluded that there is a poorly thought-out fiscal policy and a significant increase in consumption. Thus, due to the stable level of the current account deficit in Moldova, enterprises could invest and the population can consume more than if it were vice versa. Any measures that are taken to change the balance of the current account deficit of the balance of payments (e.g. changes in tariffs, quotas, exchange rates) will affect the dynamics of savings and investments. Financial crises have shown how important it is to track data on external assets and liabilities within the country's external vulnerability. Analysis of these positions becomes increasingly important factors in the context of monitoring the financial stability of the state. Thus, a significant reduction in the net borrowing indicator for the capital account in 2015 indicates the retirement of financial assets. According to the financial account (NMB), net lending / net borrowing are the net acquisition of assets minus net liabilities. Net acquisition of resources from the rest of the world should be covered either by liquidating foreign assets or by increasing liabilities of non-residents. According to the results of the financial account (NBM, 2016) for 2014-2015 there was a decline in assets and liabilities. According to the international investment position of the Republic of Moldova for 2016, the balance of external assets in relation to external liabilities decreased by 1.9 p.p., that means a net decrease in the assets of the Republic of Moldova (i.e. the amount of debts exceeds the value of the entire property of the company) (NBM, 2017).

It is to be mentioned that flows of resources are accumulating and form resource stocks. Reserves arising from the international movement of financial resources form the country's international investment position (the balance of international investment). 
Figure 10 Dynamics of financial assets and current liabilities, \%

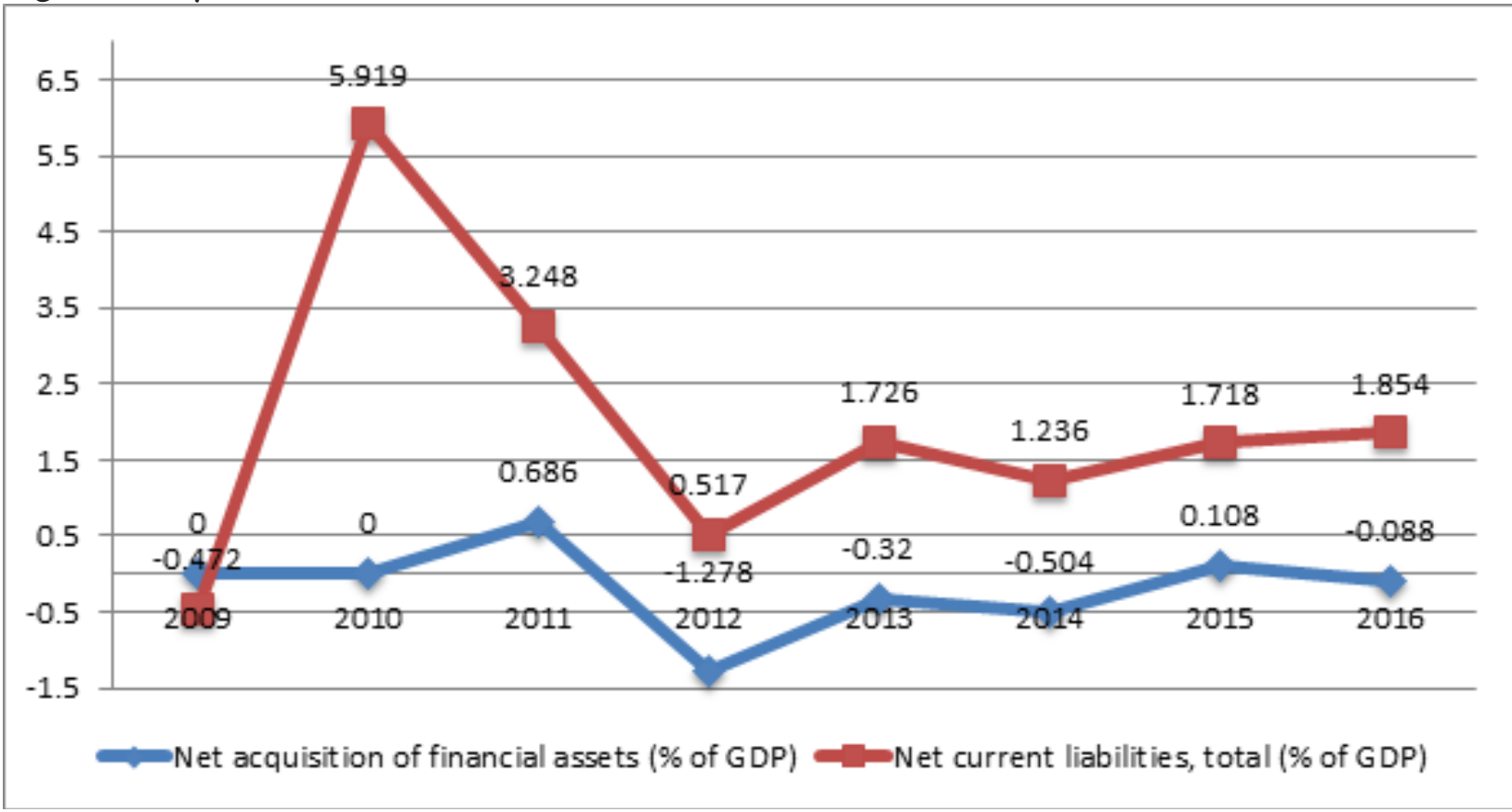

Sursa: NBM, International Investment position

In the IMF's Government Finance Statistics Manual (IMF, 2001), the change in the net asset value is the recommended quantitative indicator for assessing the degree of sustainability of fiscal activities of the state. Another reason are external transactions that can cause a change in asset holdings and financial liabilities, that can be represented as one-way actions of one country and create or decreases financial assets.

The country's balance of payments is closely linked to the economic development of this country, and reflects in a certain moment the degree and the way in which the country participates in the world economy. Thus, we can say that the balance of payments is essentially a barometer of the entire financial and economic activity of the country. This highlights the potential for the production of goods and their competitiveness in the international market, both in terms of quality and price. There is a double influence between the balance of payments and the currency: on the one hand, the exchange rate of the currency affects prices and thus increasing or decreasing the profit from international transactions, on the other hand, the balance of the payment situation has an active or a passive influence on the exchange rate of its currency. As the process of "maturing" convertibility, it will grow more and more its role in determining the mobility of convertibility of payments and exchange rates. Convertibility for success in the medium and long term, it is essential to achieve and maintain a certain balance between structural current transactions and capital and financial account. The aggregate of operations of the financial account of the balance of payments and the international investment position constitute a complete set of international accounts in the economy. At the same time, in the international financial and foreign exchange market, the quality of the country's balance of payments is an important criterion in the issuance of loans and the determination of their conditions. 


\section{CONCLUSIONS AND RECOMMENDATIONS}

Thus, through the mechanisms of transformation of savings into investment is manifested the influence of external and internal factors on financial stability and on economic development. In the conditions of the unstable economic growth of the Republic of Moldova, the risks of financial instability increase:

The reduction in gross fixed capital formation after 2009 with a low level of savings is one of the most alarming trends in the development of the national economy. Relative indicators of investment growth with a low level of gross savings can be a signal or precursor of financial instability and a decline in economic growth.

The structural imbalance between savings and investments is explained by the fact that economic growth does not have a reliable financial base, unjustified distortions in the structure of the Moldovan economy remain. The main resources for investments in the national economy are the accumulation of fixed capital, as well as current and capital transfers received from the rest of the world.

Stable shortage of payments threatens long-term economic well-being and financial stability. The main mechanism for the transmission of the crisis to the economy of the Republic of Moldova is affected by the fall in remittances. The approaching financial crisis in the Republic of Moldova is signaled by the high level of current account deficit relative to investments.

Reduction in the level of foreign direct investment shows instability of investment opportunities within the limits of the changes in the investment climate, depending on economic and political factors, as well as internal and external financial conditions. Investment activity in Moldova can be characterized as unstable and with risky conditions, which has a negative impact on attracting investors.

A significant decline in the "net borrowing" indicator for the capital account in 2015 indicates the retirement of financial assets. Analysis of assets and liabilities of IIP positions is becoming an increasingly important factor in the context of monitoring the financial stability of the state.

In the future, financial stability in Moldova will largely depend on external circumstances, and will have serious consequences not only for capital inflow and investment in future growth, but also for the formation of a new model of the country's economic development. One of the priorities for the development of the Moldovan economy would be to switch from external financing to domestic sources (which would mean reducing the vulnerability of the country's economy), including through the development of the local capital market, and therefore diversification of financial instruments in this area. Significant remittances of migrants working abroad could become an important source of investment resources for the Moldovan economy.

The leading role in the mechanism of transformation of savings into investments should belong to the National Bank of Moldova, which is called upon to contribute:

to increase the savings of the main economic entities in the form of bank deposits; the deposit guarantee fund should be increased in order to stimulate their long-term attraction to banks;

strengthening the orientation of the financial system on production and investment activities, transforming savings into investments in the real sector through the banking sector. improving the quality of integrated management of assets and liabilities of the state. 


\section{LITERATURE}

1. Capital Flows to Emerging Markets Brighter Outlook https://enterprise.press/wp-content/ uploads/2017/06/IIF-EM-report.pdf

2. International Monetary Fund http://data.imf.org/

3. McKinsey \& Company https://www.mckinsey.com/

4. National Bank of Moldova http://bnm.md/

5. National Bureau of Statistics of the Republic of Moldova www.statistica.md

6. Perciun R. (2014) Implicaţiile balanţei de plăţi asupra stabilităţii financiare a RM. International Conference "Perspective Europene Ale Pieţei Muncii. Inovare, Competenţe, Performanţă", Bucharest, Romanian Academy, National Institute for Economic Research "Costin C. Kiriţescu”, Institute for Economic Forecasting. http://econpapers.repec.org/paper/rjrwpconf/141103.htm,

7. Shneider B. (2003) Measuring Capital Flight: Estimates and Interpretations. Overseas Development Institute, London, p.9 https://www.odi.org/sites/odi.org.uk/files/odi-assets/publications-opinionfiles/2432.pdf

8. Бланшар О. (2010) Макроэкономика. М.: Издательский дом Государственного университета - Высшей иколь экономики: Глава 11. Сбережения, накопление капитала и ВВП. с. 233 -254. ISBN978-5-7598-0556-4

9. Перчун Р., Петрова Т. (2014) Финансовая безопасность Республики Молдова, LAP Lambert Academic Publishing, Germany, 119 p, ISBN: 978-3-659-45754-8, 2014

10. Сенчагова В.К. (2005) Экономическая безопасность России: Общий курс: Учебник / 2-е изд. - М.: Дело, 896 с. ISBN 5-7749-0391-5.

11. Федоров В. (2006) Рост без развития, Журнал Современная Европа, issue 2, p.5-29 http:// www.sov-europe.ru/2006.htm 